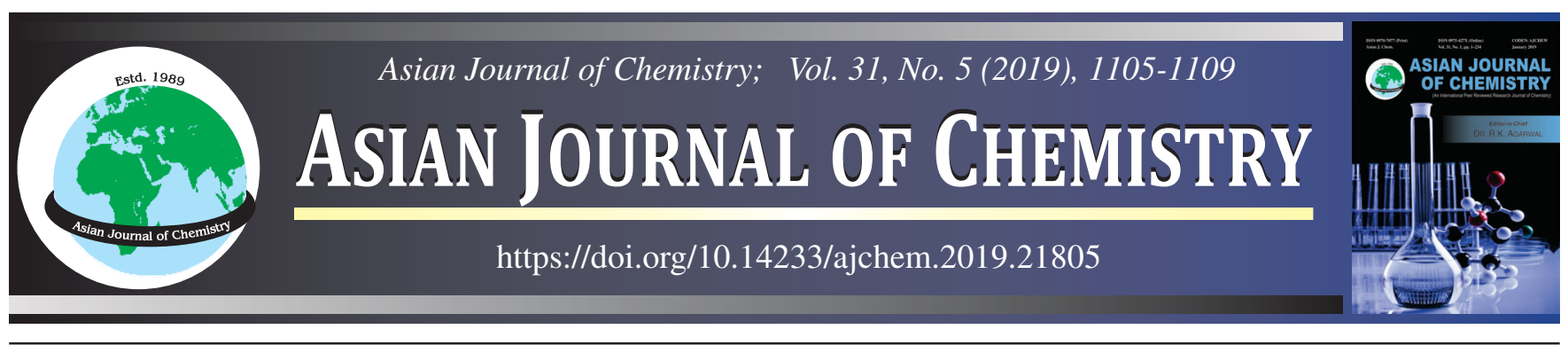

\title{
Phytochemical Study of Two Algerian Plants Origanum vulgare L. Sbsp. glandulosum (Desf) Ietswaart and Thymus algeriensis (Boiss. and Reut)
}

\author{
Farid Ait Kaki ${ }^{1,2, *}$, R. Benkiniouar ${ }^{2,3}$, I. Demirtas ${ }^{4}$, A. Merzoug ${ }^{5,6}$ and A. Touil ${ }^{2}$
}

\begin{abstract}
${ }^{1}$ Department of Chemistry, Faculty of Exacts Sciences, Mentouri Brothers University, Constantine 1, Algeria
${ }^{2}$ Laboratory of Natural Products and Organic Synthesis, Department of Chemistry, Faculty of Exacts Sciences, Mentouri Brothers University, Constantine 1, Algeria

${ }^{3}$ Department of Industrial Chemistry, Mentouri Brothers University, Constantine 1, Algeria

${ }^{4}$ Department of Chemistry, Faculty of Science, Çankiri Karatekin University, Çankiri, Turkey

${ }^{5}$ Laboratory of Applied Biochemistry, Department of Biochemistry and Cellular and Molecular Biology, Faculty of Natural Sciences, Mentouri Brothers University, Constantine 1, Algeria

${ }^{6}$ Abdelhafid Boussouf University Center, Mila, Algeria

*Corresponding author: E-mail: jskf56@yahoo.fr
\end{abstract}

Received: 10 November 2018;

Accepted: 15 January 2019;

Published online: 28 March 2019;

AJC-19339

In phytochemical study of two Algerian plants, the ethyl acetate and $n$-butanol extracts from aerial parts of Origanum vulgare L. Sbsp. glandulosum (Desf) ietswaart and $n$-butanol extract from aerial parts of Thymus algeriensis (Boiss. and Reut), one flavonoid (8,4'dihydroxy-7-O- $\beta$-D-arabinopyranosideflavone) was isolated for the first time from Origanum vulgare L. Sbsp. glandulosum ethyl acetate extract using chromatographic methods. The structure was identified on the basis of spectral analysis including UV-visible, HPLC-TOF/ MS, IR, ${ }^{1} \mathrm{H}$ NMR and ${ }^{13} \mathrm{C}$ NMR. The HPLC-TOF/MS analysis of the two $n$-butanol plants extracts showed the presence of important compounds such as phenolic acids and flavonoids. The antibacterial assay revealed that the different $n$-butanol extracts have a weak activity against the tested bacteria.

Keywords: Origanum vulgare L. Sbsp. glandulosum, Thymus algeriensis, Flavonoids, Antibacterial.

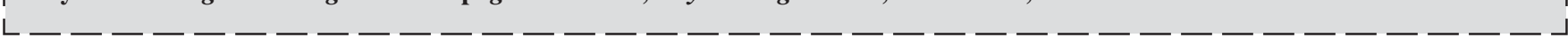

\section{INTRODUCTION}

Considered the areas bordering the Mediterranean basin are rich in therapeutic plants, especially those belonging to the Lamiaceae family [1,2]. In this study we selected two types of Algerian plants belonging to this family i.e., O. vulgare L. Sbsp. glandulosum (Desf) ietswaart and Thymus algeriensis (Boiss. and Reut). These plants are aromatic herbs and usually used as cooking spices and in folk medicine. It has been reported that they have pharmacological activities like antibacterial, stomachic, antispasmodic, antioxidant and diaphoretic [3-5]. These biological properties have been attributed to the presence of several bioactive compounds in its secondary metabolites.

Previous phytochemical studies of $O$. vulgare L. Sbsp. glandulosum and Thymus algeriensis plants have been specialized in the extraction of their volatile oils [6,7]. The aim of this work is the continuation of our research on flavonoid com- pounds from Algerian $O$. vulgare L. Sbsp. glandulosum (Desf) Ietswaart ethyl acetate [8] and $n$-butanol extracts and from n-butanol extract of Thymus algeriensis [9].

\section{EXPERIMENTAL}

Extraction protocol: In continuation of our phytochemical study, the ethyl acetate ( $20.38 \mathrm{~g}$ ) and $n$-butanol (36.48 g) extracts of $O$. vulgare L. Sbsp. glandulosum (Desf) Ietswaart [8] and $n$-butanol extract ( $8 \mathrm{~g}$ ) of Thymus algeriensis (Boiss. and Reut) [9] were extracted with chromatography protocols.

HPLC-TOF/MS analysis: HPLC-TOF/MS analysis of $O$. vulgare L. Sbsp. glandulosum and T. algeriensis extracts was carried out as described previously [10]. It was used to evaluate the phenolic acids and flavonoids in those plants extracts by comparing retention times and spectral data with those of the standard mixture chromatogram. An Agilent 6210 HPLC TOF-

This is an open access journal, and articles are distributed under the terms of the Creative Commons Attribution-NonCommercial-ShareAlike 4.0 (CC BY-NC-SA 4.0) International License which allows readers to freely read, download, copy, distribute, print, search, or link to the full texts of its articles and to use them for any other lawful non-commercial purpose as long as the original source is duly acknowledged. 
MS instrument with Zorbax SB-C18 column $(3.5 \mu \mathrm{m}, 4.6 \mathrm{~mm}$ $\times 100 \mathrm{~mm}$ ) and an injection volume of $10 \mu \mathrm{L}$ was used. The ultra-pure water with $0.1 \%$ formic acid (eluent A) and acetonitrile (eluent B) were used as mobile phases. The following linear gradient was applied: 0-1 min $10 \% \mathrm{~B} ; 1-20 \mathrm{~min} 50 \%$ B; 20-23 min $80 \%$ B; $23-25$ min $10 \%$ B; 25-30 min $10 \%$ B. The flow rate used was $0.60 \mathrm{~mL} \mathrm{~min}{ }^{-1}$ at $35{ }^{\circ} \mathrm{C}$ and TOF analyses were executed in negative ion mode.

Separation and purification of extract compound: A part of $O$. vulgare L. Sbsp. glandulosum ethyl acetate extract $(10.57 \mathrm{~g})$ was subjected to a SC6 polyamide column chromatography $(55 \times 3 \mathrm{~cm})$, being eluted with a gradient of (toluene/ $\mathrm{MeOH}$ ) with increasing polarity [8]. Twelve fractions were collected and the separated compound was obtained from fraction 8 using paper chromatography (Whatmans ${ }^{\circledR}$ No. 3$)(57 \times$ $46 \mathrm{~cm}$ ) eluted by $\mathrm{AcOH}(15 \%)$ to give 7 bands. The 4th main band with dark purple colour was purified by preparative thin layer chromatography $\left(\mathrm{CHCl}_{3} / \mathrm{MeOH}\right)(9 / 1)$ to isolate this compound. It is identified for the first time in this species.

Antibacterial activity test: The different bacteria strains; Escherichia coli (ATCC25922), Pseudomonas aeruginosa (ATCC27853), Staphylococcus aureus (ATCC25923) and Enterococcus faecalis (ATCC29212) were obtained from Abdelhafid Boussouf University Center, Mila, Algeria. The inoculums were prepared in nutrient broth from $24 \mathrm{~h}$ old bacterial cultures at $37^{\circ} \mathrm{C}$. The bacterial suspension was adjusted to $10^{8} \mathrm{UFC} / \mathrm{mL}$ with sterile saline and inoculated on the surface of Mueller-Hinton agar plates. The antibacterial activity of $n$-butanol extracts of $O$. vulgare L. Sbsp. glandulosum (Desf) Ietswaart and T. algeriensis was tested by the paper disc diffusion method against the test bacteria. The extracts were dissolved in DMSO to prepare solutions having concentration $500 \mu \mathrm{g} / \mathrm{mL}$ and $2000 \mu \mathrm{g} / \mathrm{mL}$ and then $20 \mu \mathrm{L}$ of each solution were impregnated onto sterile $6 \mathrm{~mm}$ diameter filter paper discs, ciprofloxacin $(5 \mu \mathrm{g})$ was used as positive control and DMSO
$(20 \mu \mathrm{L})$ as negative control. Growth inhibition activity was evaluated after one night incubation at $37^{\circ} \mathrm{C}$. The experiments were performed in duplicates.

\section{RESULTS AND DISCUSSION}

HPLC-TOF/MS analysis: HPLC-TOF/MS analysis showed the presence of phenolic acid and flavonoid compounds in $O$. vulgare L. Sbsp. glandulosum and T. algeriensis extracts (Table-1 and Fig. 1). However, $n$-butanol extract of T. algeriensis was richer than the extract of $O$. vulgare L. Sbsp. glandulosum. Where the first extract of the plant $T$. algeriensis, was rich with flavonoids and phenolic acid. Scutellarin was detected as a major flavonoid (2725.66 ng/mL) and 4-hydroxybenzoic acid was detected as major phenolic acid $(326.67 \mathrm{ng} / \mathrm{mL})$. Several compounds (fumaric acid, gentisic acid, naringin, diosmin, hesperidin, neohesperidin, baicalin) were detected with important concentrations. By comparing this results of $n$-butanol extract of $T$. algeriensis with the results of the analyzes obtained for the same extract [11]. It is rich in polyphenolic compounds especially in flavonoids, due to the difference in region of collection (east and central of Algeria) between the two plants and variation in extraction method and the technical method of analysis $[9,11]$. In the second plant extract of $O$. vulgare L. Sbsp. glandulosum, fumaric acid was detected as major constituent $(901.01 \mathrm{ng} / \mathrm{mL})$ and baicalin was detected as a major flavonoid $(429.20 \mathrm{ng} / \mathrm{mL})$. Several compounds (gentisic acid, syringic acid, protocatechuic acid, scutellarin, diosmin, morin) were detected with different concentrations.

Identification of separated compounds: Chromatography of $O$. vulgare L. Sbsp. glandulosum yielded only one flavonoid. The chemical structure of flavonoid was established by spectroscopic methods and comparison to literature data. The chromatographic compartment by $\mathrm{R}_{\mathrm{f}}$ shifts and the retention time value

TABLE-1

QUANTITATIVE CONTENT ANALYSIS OF PHENOLIC COMPOUNDS OF SEPARATED PHASES

\begin{tabular}{lcc|cc}
\hline \multirow{2}{*}{ Compounds } & \multicolumn{2}{c|}{ O. vulgare L. Sbsp. glandulosum. $n$-BuOH extract } & \multicolumn{2}{c}{ T. algeriensis. $n$-BuOH extract } \\
\cline { 2 - 5 } & Final concentration $(\mathrm{ng} / \mathrm{mL})$ & Retention time $(\mathrm{min})$ & Final concentration $(\mathrm{ng} / \mathrm{mL})$ & Retention time $(\mathrm{min})$ \\
\hline Fumaric acid & 901.0128 & 2.350 & 191.3905 & 2.366 \\
Gentisic acid & 79.4779 & 4.500 & 94.9105 & 4.596 \\
Chlorogenic acid & 60.5573 & 5.527 & 71.0966 & 5.543 \\
Catechin & Traces & Traces & Traces & Traces \\
4-Hydroxybenzoic acid & 49.7497 & 6.698 & 326.6758 & 6.730 \\
Protocatechuic acid & 78.2697 & 7.340 & 77.8083 & 6.987 \\
Caffeic acid & 1.6487 & 7.629 & 52.7915 & 7.677 \\
Vanillic acid & 36.4609 & 7.677 & 50.0778 & 7.917 \\
Syringic acid & 89.0487 & 8.174 & 89.5627 & 8.014 \\
Rutin & Traces & Traces & 11.7684 & 9.137 \\
Polydatine & Traces & Traces & Traces & Traces \\
Scutellarin & 160.7569 & 9.811 & 3725.6664 & 9.795 \\
Quercetin-3- $\beta$-D-glucoside & Traces & Traces & 30.8126 & 9.795 \\
Naringin & 36.9331 & 10.389 & 328.3164 & 10.132 \\
Diosmin & 164.7343 & 10.565 & 750.9427 & 10.533 \\
Hesperidin & Traces & Traces & 627.1417 & 10.661 \\
Neohesperidin & 1.7189 & 10.950 & 406.4840 & 10.661 \\
Baicalin & 429.2042 & 10.950 & 608.3731 & 10.934 \\
Salicylic acid & Traces & Traces & 96.5690 & 13.228 \\
Morin & 52.6467 & 13.871 & 52.3562 & 13.357 \\
Apigenin & 2.4428 & 15.491 & 69.9619 & 15.523 \\
\hline
\end{tabular}


(tr $=12.08 \mathrm{~min})$ using HPLC/(TOF-MS) showed that the compound is polar (glycoside), it is a monosaccharide, $\mathrm{R}_{\mathrm{f}}$ on TLC silica 0.27 ( $\left.\mathrm{SI}: \mathrm{CH}_{2} \mathrm{Cl}_{2} / \mathrm{MeOH}\right)(9 / 1), \mathrm{R}_{\mathrm{f}}$ on TLC cellulose 0.09 [SII: AcOH (15\%)]. The dark purple of spot colour under UV light changing to yellow when fumed with ammonia showed that the compound is a flavone 3-H or a flavonol 3-OR substituted. However the UV spectra in methanol and after addition of classical shift reagents suggested that the compound is a flavone with 4'-OH, substituted in position 7, without orthodihydroxyl in A and B-ring and lacking a free 5-OH [12], UV $\left(\mathrm{MeOH}, \lambda_{\max }, \mathrm{nm}\right): 268,326$; $+\mathrm{NaOH}: 276,393 ;+\mathrm{AlCl}_{3}$ : 296, 385; + $\mathrm{AlCl}_{3} / \mathrm{HCl}: 296,385$; + NaOAc: 268,387 ; + $\mathrm{NaOAc} / \mathrm{H}_{3} \mathrm{BO}_{3}$ : 268, 338 (Fig. 2).
The ${ }^{1} \mathrm{H}$ NMR analysis display $[12,13]$ a singlet signal at $6.82 \mathrm{ppm}$ attributed to $\mathrm{H} 3$, two doublets at $\delta 7.06,2 \mathrm{H}$ and $\delta$ $7.48,2 \mathrm{H}$ attributed to $\mathrm{H}^{\prime}{ }^{\prime}, \mathrm{H}^{\prime}{ }^{\prime}$ and $\mathrm{H}^{\prime}{ }^{\prime}, \mathrm{H}^{\prime}$, respectively, where the coupling constant $(J=8.5 \mathrm{~Hz})$ suggested an ortho-related between the protons, two doublets at $(\delta 6.96,1 \mathrm{H})$ and $(\delta 7.94$, $1 \mathrm{H})$ with $8.8 \mathrm{~Hz}$ of ortho-coupling constant was ascribed to $\mathrm{H} 5$ and $\mathrm{H} 6$ respectively. The using of DMSO- $d_{6}$ suggested that the position C5 is not substituted with hydroxyl $[12,13]$ so a singlet at 9.06 is attributed to $8-\mathrm{OH}$.

From the ${ }^{13} \mathrm{C}$ NMR analysis, the presence of $\mathrm{C} 3$ signal at $108.46 \mathrm{ppm}$ confirmed that the separated compound is a flavone [14-16], Other apparent signs are ${ }^{13} \mathrm{C}$ NMR (DMSO- $d_{6} ; 250$ $\mathrm{MHz}$ ): $\delta_{\mathrm{C}} 165.53$ (C2), 108.46 (C3), 147.27 (C9) [14,15,17,18].

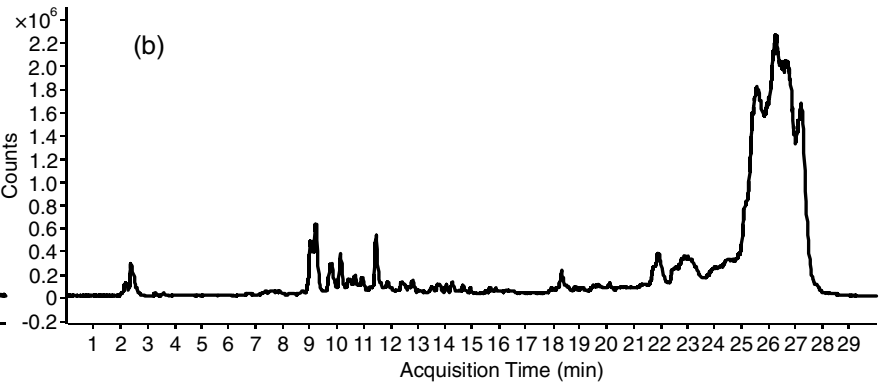

Fig. 1. HPLC chromatography for analysis of phenolic quantitative compounds in $n$-butanol extracts of O. vulgare L. Sbsp. glandulosum (a) and T. algeriensis (b)
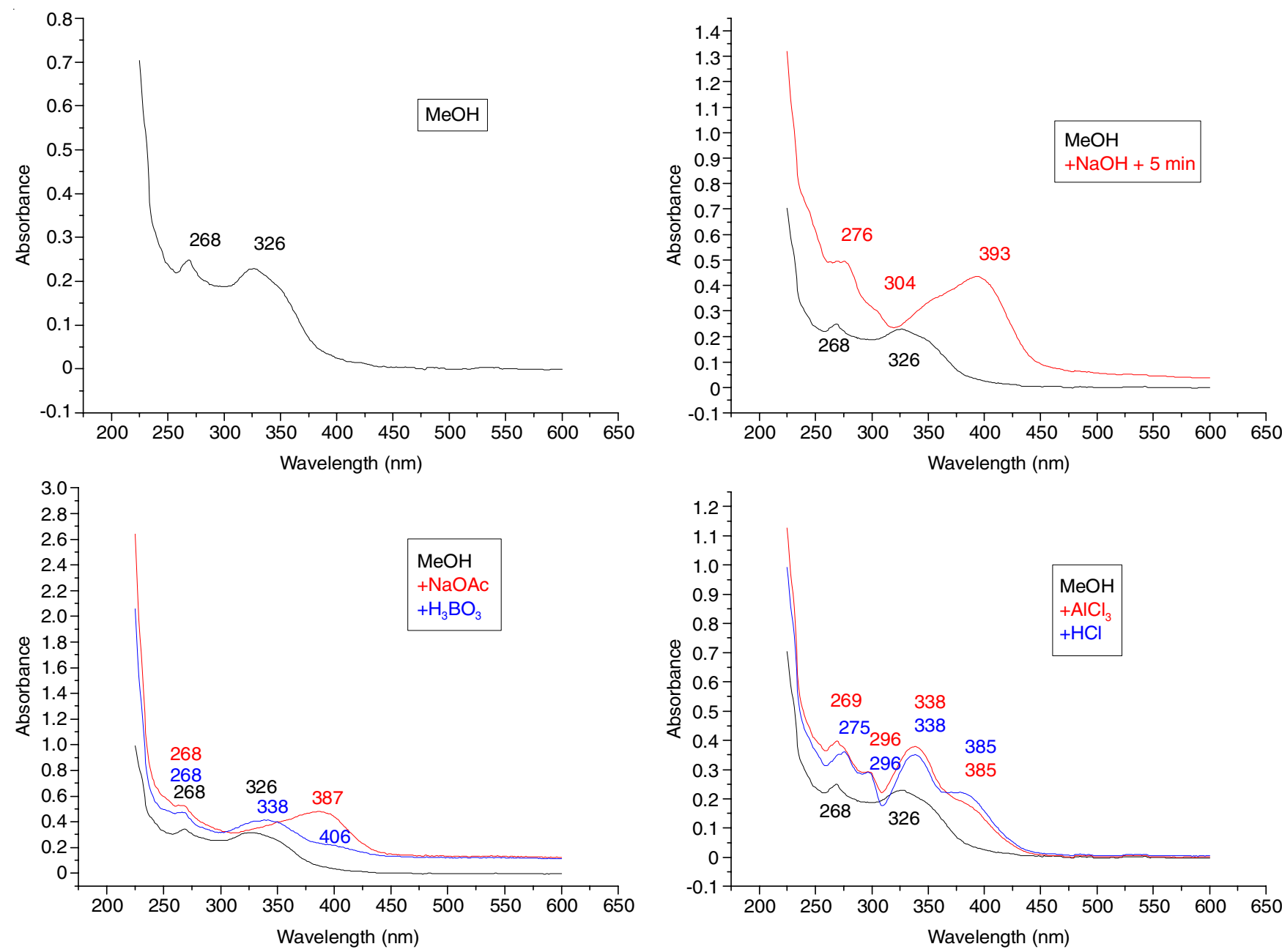

Fig. 2. UV spectra of separated compound 
TABLE-2

ANTIBACTERIAL ACTIVITY OF $O$. vulgare L. Sbsp. glandulosum AND $T$. algeriensis $n$-BUTANOL EXTRACTS

\begin{tabular}{|c|c|c|c|c|c|c|c|c|}
\hline \multirow{3}{*}{ Tested extracts } & \multicolumn{8}{|c|}{ Zone of inhibition (mm) } \\
\hline & \multicolumn{2}{|c|}{ E. coli } & \multicolumn{2}{|c|}{ S. aureus } & \multicolumn{2}{|c|}{ E. faecalis } & \multicolumn{2}{|c|}{ P. aeruginosa } \\
\hline & $\begin{array}{l}500 \mu \mathrm{g} / \mathrm{mL} \\
(5 \mu \mathrm{g} / \mathrm{disc})\end{array}$ & $\begin{array}{l}2000 \mu \mathrm{g} / \mathrm{mL} \\
(20 \mu \mathrm{g} / \mathrm{disc})\end{array}$ & $\begin{array}{l}500 \mu \mathrm{g} / \mathrm{mL} \\
(5 \mu \mathrm{g} / \mathrm{disc}) \\
\end{array}$ & $\begin{array}{l}2000 \mu \mathrm{g} / \mathrm{mL} \\
(20 \mu \mathrm{g} / \mathrm{disc})\end{array}$ & $\begin{array}{l}500 \mu \mathrm{g} / \mathrm{mL} \\
(5 \mu \mathrm{g} / \mathrm{disc})\end{array}$ & $\begin{array}{l}2000 \mu \mathrm{g} / \mathrm{mL} \\
(20 \mu \mathrm{g} / \mathrm{disc})\end{array}$ & $\begin{array}{l}500 \mu \mathrm{g} / \mathrm{mL} \\
(5 \mu \mathrm{g} / \mathrm{disc})\end{array}$ & $\begin{array}{l}2000 \mu \mathrm{g} / \mathrm{mL} \\
(20 \mu \mathrm{g} / \mathrm{disc})\end{array}$ \\
\hline$n$-butanol extract $(O . g)$ & - & $7.75 \pm 0.35$ & - & $8.5 \pm 0.7$ & 7 & 8 & - & 7 \\
\hline $\begin{array}{l}n \text {-butanol extract }(T . a) \\
\text { Ciprofloxacin }(5 \mu \mathrm{g})\end{array}$ & $30.5 \pm 0.7$ & $=0.7^{7}$ & $\begin{array}{l}7 \\
32\end{array}$ & $2.82^{8}$ & $34 \pm 0.7$ & 0.7 & $29.5 \pm 0.7$ & $\begin{array}{rl} & 6.5 \pm 0.7 \\
上 & 0.7\end{array}$ \\
\hline
\end{tabular}

- Indicates no zone of inhibition. The negative control did not show any activity.

The molecular formula of the separated compound was determined as $\mathrm{C}_{20} \mathrm{O}_{9} \mathrm{H}_{18}$ by negative ion mode ESI mass spectra $\left(\mathrm{m} / z 401[\mathrm{M}-\mathrm{H}]^{-}\right)$, it showed that the compound is a monosaccharide and the corresponding sugar is arabinose $\mathrm{C}_{5} \mathrm{O}_{5} \mathrm{H}_{10}$.

Referring to the ${ }^{1} \mathrm{H}$ NMR analysis, the chemical shifts of protons sugar signals increased to the range $\left[\delta_{\mathrm{H}} 3.7-5.1 \mathrm{ppm}\right]$ due to the effect of solvent (DMSO- $\left.d_{6}+\mathrm{H}_{2} \mathrm{O}\right)$ [13], where the anomeric proton $\mathrm{H}^{\prime \prime}$ signal for this sugar is shown as a doublet at $5.05 \mathrm{ppm}$ and $7.1 \mathrm{~Hz}$ resulting of (axial-axial) coupling with $\mathrm{H} 2$ ", which indicate that sugar is $\beta$-linked to aglycone [19]. Other protons of sugar moiety are $\delta_{\mathrm{H}} 4.19\left(1 \mathrm{H}, \mathrm{d}-\mathrm{d}, J=8, \mathrm{H} 2^{\prime \prime}\right)$, $3.75\left(1 \mathrm{H}, \mathrm{d}-\mathrm{d}, J=6, \mathrm{H} 3^{\prime \prime}\right), 4.11\left(1 \mathrm{H}, \mathrm{t}, J=6.2, \mathrm{H} 4^{\prime \prime}\right)$ and 3.85 (2H, d, H5").

By comparing the carbons chemical shifts of sugar $\delta_{\mathrm{C}}$ 70.45 (C2"), 70.45 (C3"), 70.12 (C4"), 63.08 (C5") with those published by Agrawal [14] and taking the previous sugar mass, the final formulation being $\beta$-D-arabinopyranoside.

The comparison between the IR data with published by Parker and Tipson [20] and Agrawal [14], showed the presence of absorption bands for hydroxyl flavonoid or phenolic group $[20,21] 3444.6 \mathrm{~cm}^{-1}$, carbonyl flavone [14] and conjugated double bond for $\mathrm{C} 2$ and $\mathrm{C} 31650 \mathrm{~cm}^{-1}$ [20], the strong absorption band at $825.5 \mathrm{~cm}^{-1}$ was indicative of (Ctri-H aromatic) for aromatic cycle para-disubstituted [20,21], it's for (H2', H3') and (H5', H6') of B-ring, another at $763.8 \mathrm{~cm}^{-1}$ due to (Ctri-H aromatic) for aromatic cycle ortho-disubstituted [20,21], it's for H5, H6 of A-ring. Most flavonoid glycosides is characterized by broad bands at 3250 and $1060 \mathrm{~cm}^{-1}$ [14], however the glycoside part of this compound we discover it by two bands at $1041.5 \mathrm{~cm}^{-1}$ for (C-O-C) [20] and $1010.6 \mathrm{~cm}^{-1}$ for (C-C) [21]. Various spectral data demonstrated that the structure of this compound should be the 8,4'-dihydroxy-7O- $\beta$-D-arabinopyranosideflavone.

Antibacterial assay: The antibacterial property was tested against two Gram-positive bacteria, which are S. aureus and $E$. faecalis and two Gram-negative bacteria namely E. coli and $P$. aeruginosa, with DMSO as a negative bacteria growth inhibition test and ciprofloxacin as standard drug.

According to Table-2, the inhibition zone produced ranged between 6.5 and $8.5 \mathrm{~mm}$, which indicate that the extracts of $O$. vulgare L. Sbsp. glandulosum and T. algeriensis showed weak activity against the tested bacteria. The growth inhibition activity of T. algeriensis (Boiss. and Reut) essential oils have been investigated before by others authors [7,22], but in present study we tested the antibacterial activity of $n$-butanol extract from the aerial parts of this plant [9].

The antibacterial activity of $n$-butanol extract of $O$. vulgare L. Sbsp. glandulosum (Desf) Ietswaart was studied in continuation of our investigation carried out on this medicinal plant [8]. Our results showed that the $n$-butanol extract had less antibacterial activity than the ethyl acetate extract [8]. An introspection of this result revealed that the antibacterial effect depend upon the components in these two different extracts.

\section{Conclusion}

One compound, 8,4'-dihydroxy-7-O- $\beta$-D-arabinopyranoside flavone, was isolated for the first time from $O$. vulgare L. Sbsp. glandulosum (Desf) Ietswaart ethyl acetate extract, the HPLC-TOF/MS analysis of $O$. vulgare L. Sbsp. glandulosum and $T$. algeriensis $n$-butanol extracts showed the presence of new and important flavonoids. The Antibacterial assays showed that the different $n$-butanol extracts have a weak activity.

\section{CONFLICT OF INTEREST}

The authors declare that there is no conflict of interests regarding the publication of this article.

\section{REFERENCES}

1. T.G. Tutin, V.H. Heywood, N.A. Burges, D.M. Moore, D.H. Valentine, S.M. Walters and D.A. Webb, Flora Europaea, Cambridge University Press: Cambridge, vol. 3 (1968).

2. F.A. Tomas-Barberan, M.I. Gil, F. Ferreres and F. Tomas-Lorente, Phytochemistry, 31, 3097 (1992);

https://doi.org/10.1016/0031-9422(92)83452-5.

3. L. Boulos, Medicinal Plants of North Africa, Reference Publications. Inc: Michigan, USA (1983).

4. J.H. Ietswaart, A Taxonomic Revision of the Genus Origanum (Labiateae), In: Chemical Composition and Antioxidant Activity of Essential Oils from Algerian Origanum glandulosum Desf, Leiden Botanical, Leiden University Press: La Haye, series 4 (1980).

5. J. Valnet, Aromathérapie traitement des maladies par les essences des plantes, Maloine S.A.: Paris, edn 10 (1984).

6. K. Mechergui, W. Jaouadi, J.P. Coelho and M.L. Khouja, Ind. Crops Prod., 90, 32 (2016); https://doi.org/10.1016/j.indcrop.2016.06.011.

7. A. Jayari, N. El Abed, A. Jouini, O. Mohammed Saed Abdul-Wahab, A. Maaroufi and S. Ben Hadj Ahmed, J. Food Saf., 38, e12409 (2018); https://doi.org/10.1111/jfs.12409.

8. F. Ait Kaki, R. Benkiniouar, A. Zellagui, S. Rhouati and F. Zaidi, J. Academica, 5, 3 (2015).

9. R. Benkiniouar, S. Rhouati, A. Touil, E. Seguin and E. Chosson, Chem. Nat. Compd., 43, 321 (2007); https://doi.org/10.1007/s10600-007-0118-x.

10. G. Abay, M. Altun, S. Koldas, A.R. Tüfekçi and I. Demirtas, Comb. Chem. High Throughput Screen., 18, 453 (2015); https://doi.org/10.2174/1386207318666150305112504.

11. N. Boutaoui, L. Zaiter, F. Benayache, S. Benayache, S. Carradori, S. Cesa, A.M. Giusti, C. Campestre, L. Menghini, D. Innosa and M. Locatelli, Molecules, 23, 463 (2018); https://doi.org/10.3390/molecules23020463.

12. K.R. Markham, Techniques of Flavonoid Identification, Academic Press: London (1982). 
13. T.J. Mabry, K.R. Markham and M.B. Thomas, The Systematic Identification of Flavonoids, Springer-Verlag: Berlin (1970).

14. P.K. Agrawal, Carbon-13 NMR of Flavonoids, Elsevier: New York, edn 1 (1989).

15. M. Iinuma, S. Matsuura and K. Kusuda, Chem. Pharm. Bull., 28, 708 (1980); https://doi.org/10.1248/cpb.28.708.

16. P. Joseph-Nathan and R.L. Santillán, Spectrochim. Acta, 40, 1077 (1984); https://doi.org/10.1016/0584-8539(84)80136-1.

17. K.R. Markham and B. Ternai, Tetrahedron, 32, 2607 (1976); https://doi.org/10.1016/0040-4020(76)88036-2

18. H. Wagner, V.M. Chari and J. Sonnenbichler, Tetrahedron Lett., 17, 1799 (1976);

https://doi.org/10.1016/S0040-4039(00)93787-0.
19. J.B. Harborne, The Flavonoids: Advances in Research since 1980, Chapman and Hall: London (1988).

20. R.S. Tipson and F.S. Parker, Applications of IR spectroscopy in Biochemistry, Biology and Medicine, Hilger: London (1971).

21. Teacher's Sheet, Spectral Analysis: IR and NMR spectroscopy; https://phychim.ac-versailles.fr/IMG/pdf/Documents-formationspectroscopies.pdf.

22. I. Ben El Hadj Ali, M. Chaouachi, R. Bahri, I. Chaieb, M. Boussaid and F. Harzallah-Skhiri, Ind. Crops Prod., 77, 631 (2015); https://doi.org/10.1016/j.indcrop.2015.09.046. 